\title{
A HYBRID LINGUISTIC FUZZY MULTIPLE CRITERIA GROUP SELECTION OF A CHIEF ACCOUNTING OFFICER
}

\author{
Violeta Keršuliene் ${ }^{1}$, Zenonas Turskis ${ }^{2}$ \\ ${ }^{1}$ Department of Law, Faculty of Business Management, Vilnius Gediminas \\ Technical University, Sauletekio al. 11, LT-10223 Vilnius, Lithuania \\ ${ }^{2}$ Department of Construction Technology and Management, Faculty of Civil Engineering, \\ Vilnius Gediminas Technical University, Sauletekio al. 11, LT-10223 Vilnius, Lithuania \\ E-mail: 1violeta.kersuliene@vgtu.lt (correspondingauthor); ${ }^{2}$ zenonas.turskis@vgtu.lt
}

Received 16 January 2014; accepted 07 March 2014

\begin{abstract}
In the preceding decade, economic and social costs brought by financial statement fraud have shaken markets, devastated investment portfolios and reduced confidence in financial reporting. A financial department is special in the way it needs to conform to standards. Many individual attributes considered for the selection of a chief accounting officer, such as organisational skills, personality, leadership etc. This paper focuses on a fuzzy multi-criteria decision making (MCDM) algorithm, which integrates the principles of fusion of fuzzy information, additive ratio assessment method with fuzzy numbers (ARAS-F), fuzzy weighted-product model and analytic hierarchy process (AHP). The proposed method is apt to manage information assessed using both linguistic and numerical scales in a decision making problem with a group of information sources. The computational procedure is illustrated through the problem related to the selection of a chief accounting officer.
\end{abstract}

Keywords: personnel selection, accountant, linguistic representation, ARAS-F, AHP, MCDM, decision making.

Reference to this paper should be made as follows: Keršulienè, V.; Turskis, Z. 2014. A hybrid linguistic fuzzy multiple criteria group selection of a chief accounting officer, Journal of Business Economics and Management 15(2): 232-252.

JEL Classification: J01, J24, M41, M54, C44.

\section{Introduction}

In most cases, modern real-world problems cannot be solved only by considering precise and objective information. Existing work in data mining from multiple data sources mainly falls into the following three categories:

a) Data integration;

b) Model integration;

c) Relational learning. 
The first objective of this study is to develop a decision making approach to a problem of multiple information sources, which enables the incorporation of both crisp data and fuzzy data represented as linguistic variables or triangular fuzzy numbers into the analysis.

The second objective of this paper is to construct a Model for Selection of a Chief Accounting Officer based on the study of ways used by stakeholders selecting chief accounting officers. The presented model reduces the time taken by stakeholders and managers to accumulate experience in selection of a chief accounting officer, further increasing the efficiency of the enterprises activities.

Human resources are one of the core competences for an organisation to enhance its competitive advantage in the knowledge economy (Lin 2010). Personnel selection is the process of choosing among candidates, who match the qualifications required to perform a defined job in the best way (Dursun, Korsak 2010). The use of personality measures to predict job performance has a long and storied history (Penney et al. 2010). However, methodological advances in meta-analytic techniques and the advent of the now widely-accepted Big Five Model of Personality - Conscientiousness, Extraversion, Agreeableness, Emotional Stability and Openness to Experience - renewed the interest in personality as a selection device among academics.

Kelemenis et al. (2011) presented an overview of recent studies on the personnel selection problem (1992 to 2009). They indicated the use of different techniques and conceptual models. The quality of human capital is crucial for high-tech companies to maintain competitive advantages in knowledge economy era (Chien, Chen 2008). The fuzzy set appears as an essential tool to provide a decision framework that incorporates imprecise judgements inherent to the personnel selection process (Dursun, Korsak 2010).

A financial management department is special in the way it needs to conform to standards, which is different from any other department. Evaluation criteria for financial management are listed in Figure 1.

There are two fields of accounting: financial and managerial. Management accounting provides customised, appropriate and timely financial information to those internal managers entrusted with the day-to-day operations of the organisation. Lambert and Pezet

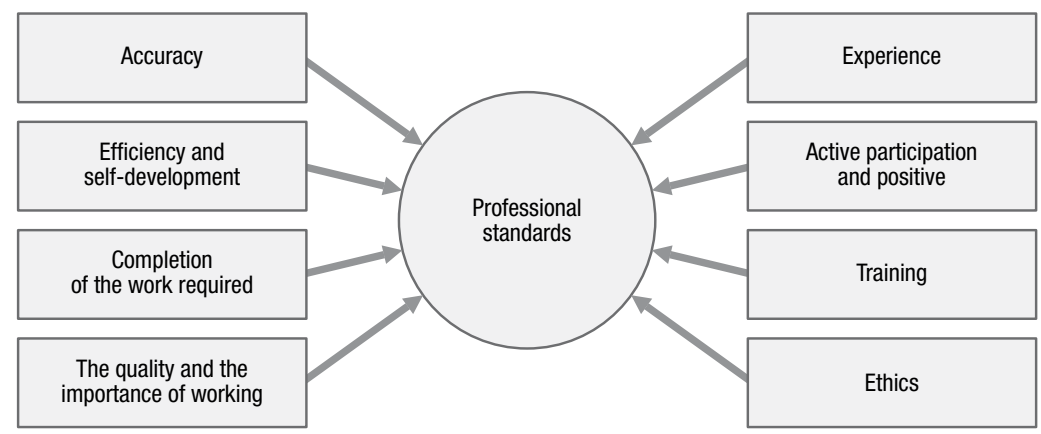

Fig. 1. List of professional standards as the basis for evaluation of financial management 
(2011) analysed the practices through which a management accountant is constructed as a knowing subject and becomes a producer of truthful knowledge. The centrality of management accountant's role is evidenced, among other aspects, by their participation in online reverse auctions, wherein they commit themselves and their company to long-term projects.

Chiapello and Medjad (2009) highlighted that accounting standards concern a far greater audience than market actors (companies, auditors, bankers and investors).

In the last two decades or so there has been a lively academic and political debate about the continued gendering process of the accountancy profession (Heidhues, Patel 2011). Accountancy is now well established as an elite professional occupation in most parts of the world and much of this status has been afforded through an association with educational qualifications (Gammie, Kirkham 2008). Seifert et al. (2010) applied the theory of organisational justice to the design of whistle blowing policies and procedures. The emphasis in financial accounting is on producing organisational summaries of financial consequences of past activities and decisions. The prepared data is objective, precise and verifiable, usually by an external auditor.

Tillmann and Goddard (2008) developed a substantive grounded theory of strategic management accounting and sense-making. It is not enough to 'simply' know accounting or management accounting techniques, but there is a need for a much broader knowhow. Accounting is not a 'reality' in itself, but part of broader organisational realities for whose understanding some non-accounting knowledge is needed.

Jones and Lee (1998) stated that in recent years there have been concerns for 'traditional' accounting approaches to investment appraisal hinder companies' adoption of advanced manufacturing technology. Primrose (1988) warned that traditional accounting methods, when faced with engineering problems in trying to justify advanced manufacturing technology have resulted in many companies investing in wrong technologies or for wrong reasons. Some organisations (e.g. governmental departments) distinguish between 'essential' and 'desirable' criteria. Essential criteria are those elements or conditions of a job that the employer considers vital for successful performance in a particular role. Desirable criteria are the ones that are nice to have and may be of assistance in the role. In highly-competitive recruitment situations, being able to address all the desirable criteria may be necessary; however, do not be put off applying for a role if you can address all the essential criteria.

Accurately defining performance criteria is a critical step in empirical validation. However, defining performance criteria is also a conceptual issue, as criteria should accurately represent all important performance requirements of the target job (Penney, Borman 2005).

Applying the factor analysis research method, Lin (2008) has empirically-developed 6 latent constructs about the desirable knowledge and skill components that should be emphasized in accounting education in order to meet the challenges stemming from the changing business environment, i.e. business/management skills, business/management knowledge, core accounting knowledge, personal characteristics, general knowl- 
edge and basic techniques. The structural order of/the interrelationship among these six dimensions of knowledge and skill requirements in accounting education is also elaborated based on the analysis of factor loading results.

\section{Selection algorithm based on the fuzzy sets and MCDM methods}

There are a lot of different MCDM methods. Selection of an appropriate decision method depends on the aim of the problem, available information, cost of the decision and qualification of actors (decision-makers).

The type of information collected can directly influence scale construction. Different types of information could be measured in different ways:

a) At the nominal level. That is, any numbers used are mere labels: they express no mathematical properties.

b) At the ordinal level. Numbers indicate the relative position of items, but not the magnitude of difference. An example is a preference ranking.

c) At the interval level. Numbers indicate the magnitude of difference between items, but there is no absolute zero point. Examples are attitude scales and opinion scales.

d) At the ratio level. Numbers indicate magnitude of difference and there is a fixed zero point. Examples include: age, income, price, costs, sales revenue, sales volume, and market share.

A wider overview of MCDM methods, classification and applications are presented by Zavadskas and Turskis (2011). In this research, two of them are applied: ARAS-F and AHP. The multiple-criteria expert system for problem solving can be described as shown in Figure 2.

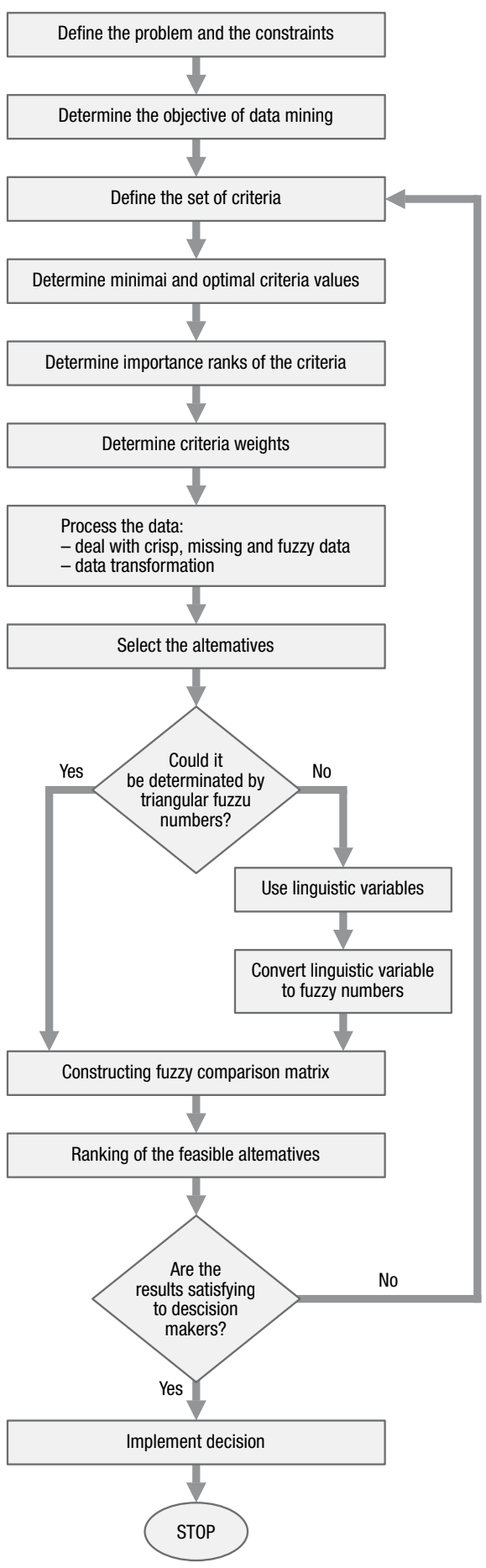

Fig. 2. The multiple-criteria expert system for personnel selection 


\subsection{Basic definitions}

Fuzzy set theory, which was introduced by Zadeh (1975a, 1975b, 1975c). A fuzzy set can be defined mathematically by a membership function, which assigns each element $\mathrm{x}$ in the universe of discourse $\mathrm{X}$ a real number in the interval $[0,1]$.

A triangular fuzzy number can be defined by a triplet $(\alpha, \gamma, \beta)$ as illustrated in Figure 3 .

A fuzzy set is a class of objects with a continuum of membership grades. Such a set is characterized by a membership function which assigns to each object a grade of membership ranging between zero and one (Zadeh 1975a, 1975b, 1975c). A fuzzy set $A$ defined in space $X$ is a set of pairs:

$$
A=\left\{\left(x, \mu_{A}(x)\right), x \in X\right\}, \forall x \in X,
$$

where the fuzzy set $A$ is characterized by its membership function $\mu_{A}: X \rightarrow[0 ; 1]$ which associates with each element $x \in X$, with a real number $\mu_{A}(x) \in[0 ; 1]$. The value $\mu_{A}(x)$ at $x$ represents the grade of membership of $x$ in $A$ and is interpreted as the membership degree to which $x$ belongs to $A$. So the closer the value $\mu_{A}(x)$ is to 1 , the more $x$ belongs to $A$.

A crisp or ordinary subset $A$ of $X$ can also be viewed as a fuzzy set in $X$ with membership function as its characteristic function, i.e.

$$
\mu_{A}(x)=\left\{\begin{array}{l}
1, x \in A \\
0, x \notin A
\end{array} .\right.
$$

The set $X$ is called a universe of discourse. A fuzzy set $A$ in $X$ can be represented as $A=\left\{\left(x, \mu_{A}(x)\right)\right\}$, where $x \in X$ and $\mu_{A}: X \rightarrow[0 ; 1]$.

When the universe of discourse is discrete and finite with cardinality $n$, that is $X=\left\{x_{1}, x_{1}, \ldots, x_{n}\right\}$, the fuzzy set $A$ can be represented as (Zadeh 1975d; Klir, Yuan 1995):

$$
A=\sum_{i=1}^{n} \frac{\mu_{A}\left(x_{i}\right)}{x_{i}}=\frac{\mu_{A}\left(x_{1}\right)}{x_{1}}+\frac{\mu_{A}\left(x_{2}\right)}{x_{2}}+\cdots+\frac{\mu_{A}\left(x_{n}\right)}{x_{n}} .
$$

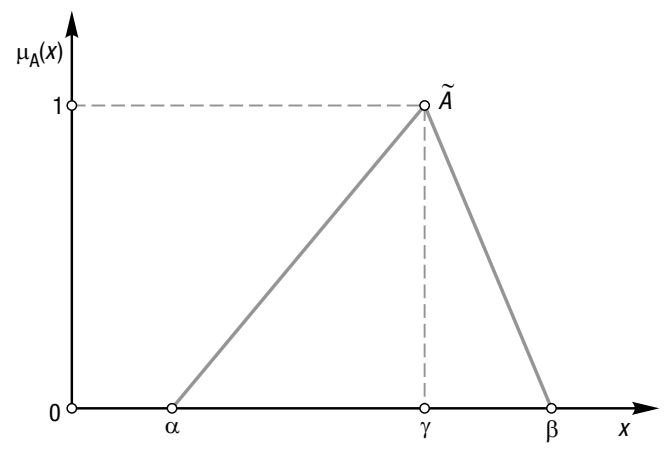

Fig. 3. Triangular membership function 
When the universe of discourse $X$ is an interval of real numbers, the fuzzy set $A$ can be expressed as:

$$
A=\int_{X} \frac{\mu_{A}(x)}{x} .
$$

A fuzzy number is defined to be a fuzzy triangular number $(\alpha, \beta, \gamma)$ if its membership function is fully described by three parameters $(\alpha<\gamma<\beta)$ :

$$
\mu_{A}(x)= \begin{cases}\frac{1}{\gamma-\alpha} x-\frac{\alpha}{\gamma-\alpha}, & \text { if } x \in[\alpha, \gamma] \\ \frac{1}{\beta-\gamma} x-\frac{\beta}{\beta-\gamma} & , \text { if } x \in[\gamma, \beta] \\ 0 & , \text { otherwise. }\end{cases}
$$

In order to obtain a crisp output, a defuzzification process is needed to be applied.

Various types of membership functions are used. The most typical fuzzy set membership function is triangular membership function (Fig. 3).

The basic operations of fuzzy triangular numbers $\tilde{n}_{1}$ and $\tilde{n}_{2}$ (Van Laarhoven, Pedrycz 1983) are defined as follows:

$$
\begin{aligned}
\tilde{n}_{1} \oplus \tilde{n}_{2} \cong\left(n_{1 \alpha}+n_{2 \alpha}, n_{1 \gamma}+n_{2 \gamma}, n_{1 \beta}+n_{2 \beta}\right) & \text { for addition, } \\
\tilde{n}_{1}(-) \tilde{n}_{2} \cong\left(n_{1 \alpha}-n_{2 \beta}, n_{1 \gamma}-n_{2 \gamma}, n_{1 \beta}-n_{2 \alpha}\right) & \text { for substraction, } \\
\tilde{n}_{1} \otimes \tilde{n}_{2} \cong\left(n_{1 \alpha} \otimes n_{2 \alpha}, n_{1 \gamma} \otimes n_{2 \gamma}, n_{1 \beta} \otimes n_{2 \beta}\right) & \text { for multiplication, } \\
\tilde{n}_{1}(\div) \tilde{n}_{2} \cong\left(\frac{n_{1 \alpha}}{n_{2 \beta}}, \frac{n_{1 \gamma}}{n_{2 \gamma}}, \frac{n_{1 \beta}}{n_{2 \alpha}}\right) & \text { for division, } \\
k \tilde{n}_{1} \cong\left(k n_{1 \alpha}, k n_{1 \beta}, k n_{1 \gamma}\right) & \text { for multiplication by constant, } \\
\left(\tilde{n}_{1}\right)^{-1} \cong\left(\frac{1}{n_{1 \beta}}, \frac{1}{n_{1 \gamma}}, \frac{1}{n_{1 \alpha}}\right) & \text { for division, } \\
\ln \left(\tilde{n}_{1}\right) \cong\left(\ln \left(\tilde{n}_{1 \alpha}\right), \ln \left(\tilde{n}_{1 \gamma}\right), \ln \left(\tilde{n}_{1 \beta}\right)\right) & \text { for natural logarithm, } \\
\exp \left(\tilde{n}_{1}\right) \cong\left(\exp \left(\tilde{n}_{1 \alpha}\right), \exp \left(\tilde{n}_{1 \gamma}\right), \exp \left(\tilde{n}_{1 \beta}\right)\right) & \text { for exponential. }
\end{aligned}
$$

\subsection{Additive Ratio Assessment method (ARAS) with fuzzy criteria values (ARAS-F)}

This section outlines the fuzzy MCDM approach, which is based on ARAS with fuzzy criteria values method. ARAS method was developed by Zavadskas and Turskis (2010). Later, modifications of ARAS method - ARAS-G (grey relations are applied) and ARASF - were published (Turskis, Zavadskas 2010a, 2010b; Turskis et al. 2012). There are only few applications of ARAS method (Tupenaite et al. 2010; Zavadskas et al. 2010b, 2012a; Bakshi, Sarkar 2011; Sušinskas et al. 2011; Keršulienė, Turskis 2011). 
According to the ARAS method, a utility function value determining the complex relative efficiency of a reasonable alternative is directly proportional to the relative effect of values and weights of the main criteria considered in a project.

The first stage is dedicated to forming of the fuzzy decision-making matrix (FDMM). Any problem which has to be solved is represented by the following decision-making matrix (DMM) of preferences for $m$ reasonable alternatives (rows) rated on $n$ criteria (columns):

$$
\begin{gathered}
\tilde{X}=\left[\begin{array}{ccccc}
\tilde{x}_{01} & \cdots & \tilde{x}_{0 j} & \cdots & \tilde{x}_{0 n} \\
\vdots & \ddots & \vdots & \ddots & \vdots \\
\tilde{x}_{i 1} & \cdots & \tilde{x}_{i j} & \cdots & \tilde{x}_{i n} \\
\vdots & \ddots & \vdots & \ddots & \vdots \\
\tilde{x}_{m 1} & \cdots & \tilde{x}_{m j} & \cdots & \tilde{x}_{m n}
\end{array}\right], \\
i=\overline{0, m} ; j=\overline{1, n}
\end{gathered}
$$

where $m$ - number of alternatives, $n$ - number of criteria describing each alternative, $\tilde{x}_{i j}$ - fuzzy value representing the performance value of the $i$ alternative in terms of the $j$ criterion, $\tilde{x}_{0 j}$ - optimal value of $j$ criterion. A tilde " $\sim$ " will be placed above a symbol if the symbol represents a fuzzy set.

If optimal value of $j$ criterion is unknown, then:

$$
\begin{aligned}
& \tilde{x}_{0 j}=\max _{i} \tilde{x}_{i j}, \quad \text { if } \max _{i} \tilde{x}_{i j} \text { is preferable, and } \\
& \tilde{x}_{0 j}=\min _{i} \tilde{x}_{i j}^{*}, \quad \text { if } \min _{i} \tilde{x}_{i j}^{*} \text { is preferable. }
\end{aligned}
$$

Usually, the performance values $\tilde{x}_{i j}$ and the criteria weights $\tilde{w}_{j}$ are viewed as the entries of a DMM. The system of criteria as well as the values and initial weights of criteria are determined by experts.

The purpose of the next stage is to calculate dimensionless-normalized values. The initial values of all criteria are normalized - defining values $\tilde{\bar{x}}_{i j}$ of normalised decisionmaking matrix $\tilde{\bar{X}}$ :

$$
\begin{gathered}
\tilde{\bar{X}}=\left[\begin{array}{ccccc}
\tilde{\bar{x}}_{01} & \ldots & \tilde{\bar{x}}_{0 j} & \ldots & \tilde{\bar{x}}_{0 n} \\
\vdots & \ddots & \vdots & \ddots & \vdots \\
\tilde{\bar{x}}_{i 1} & \ldots & \tilde{\bar{x}}_{i j} & \ldots & \tilde{\bar{x}}_{i n} \\
\vdots & \ddots & \vdots & \ddots & \vdots \\
\tilde{\bar{x}}_{m 1} & \ldots & \tilde{\bar{x}}_{m j} & \ldots & \tilde{\bar{x}}_{m n}
\end{array}\right] . \\
i=\overline{0, m} ; j=\overline{1, n} .
\end{gathered}
$$

The criteria, whose preferable values are maxima, are normalized as follows:

$$
\tilde{\bar{x}}_{i j}=\frac{\tilde{x}_{i j}}{\sum_{i=0}^{m} \tilde{x}_{i j}} .
$$


The criteria, whose preferable values are minima, are normalized by applying two-stage procedure:

$$
\tilde{x}_{i j}=\frac{1}{\tilde{x}_{i j}^{*}} ; \quad \tilde{\bar{x}}_{i j}=\frac{\tilde{x}_{i j}}{\sum_{i=0}^{m} \tilde{x}_{i j}} .
$$

The third stage is defining normalized-weighted matrix $-\tilde{\hat{X}}$. It is possible to evaluate the criteria with weights $0<\tilde{w}_{j}<1$. The values of weight $w_{j}$ are usually determined by the expert evaluation method. The sum of weights $w_{j}$ would be limited as follows:

$$
\begin{gathered}
\sum_{j=1}^{n} w_{j}=1, \\
\tilde{\hat{X}}=\left[\begin{array}{ccccc}
\tilde{\hat{x}}_{01} & \cdots & \tilde{\hat{x}}_{0 j} & \cdots & \tilde{\hat{x}}_{0 n} \\
\vdots & \ddots & \vdots & \ddots & \vdots \\
\tilde{\hat{x}}_{i 1} & \cdots & \tilde{\hat{x}}_{i j} & \cdots & \tilde{\hat{x}}_{i n} \\
\vdots & \ddots & \vdots & \ddots & \vdots \\
\tilde{\hat{x}}_{m 1} & \cdots & \tilde{\hat{x}}_{m j} & \cdots & \tilde{\hat{x}}_{m n}
\end{array}\right], \\
i=\overline{0, m} ; j=\overline{1, n} .
\end{gathered}
$$

Normalized-weighted values of all the criteria are calculated as follows:

$$
\tilde{\hat{x}}_{i j}=\tilde{\bar{x}}_{i j} \tilde{w}_{j} ; i=\overline{0, m},
$$

where $w_{j}$ is the weight (importance) of the $j$ criterion and $\bar{x}_{i j}$ is the normalized rating of the $j$ criterion.

The following step is determining values of effectiveness function:

$$
\tilde{S}_{i}=\sum_{j=1}^{n} \tilde{\hat{x}}_{i j} ; \quad i=\overline{0, m}
$$

where $\tilde{S}_{i}$ is the value of effectiveness function of $i$-th alternative.

The greater the value of the effectiveness function $\tilde{S}_{i}$, the more effective is the alternative.

The result of fuzzy decision making for each alternative is fuzzy number $\tilde{S}_{i}$. The centreof-area is the most practical and simple to apply for defuzzification:

$$
S_{i}=\frac{1}{3}\left(S_{i \alpha}+S_{i \beta}+S_{i \gamma}\right)
$$

The utility degree $K_{i}$ of an alternative $A_{i}$ is determined by a comparison of the variant, which is analysed, with the most ideal one $S_{0}$ :

$$
K_{i}=\frac{S_{i}}{S_{0}} ; \quad i=\overline{0, m},
$$

where $S_{i}$ and $S_{0}$ are the optimal criterion values, obtained from Eq. (23).

The complex relative efficiency of the reasonable alternative can be determined according to the utility function values. 


\subsection{A fuzzy weighted-product model}

Triantaphyllou and Lin (1995) presented the fuzzy weighted-product model (WPM). The WPM uses multiplication to rank alternatives. Each alternative is compared with others by multiplying a number of ratios, one for each criterion. Each ratio is raised to the power of a respective weight.

The two alternatives can be compared as follows:

$$
R\left(\frac{A_{K}}{A_{L}}\right)=\prod_{j=1}^{n}\left(\frac{\tilde{a}_{K j}}{\tilde{a}_{L j}}\right)^{\tilde{w}_{j}},
$$

where $\tilde{a}_{K j}, \tilde{a}_{L j}$, and $\tilde{w}_{j}$ are fuzzy triangular numbers. Alternative $A_{K}$ dominates alternative $A_{L}$ if and only if the numerator in Eq. (25) is greater than the denominator.

\subsection{Determining criteria weights with the help of AHP}

Methods of utility theory based on qualitative initial measurements include two widely known groups of methods: AHP and fuzzy set theory methods (Zimmermann 1985, 2000). Pioneering studies presented by Saaty (Saaty 1977, 1980; Saaty, Zoffer 2011). Lootsma (1993) introduced Multiplicative AHP, which is an exponential version of the simple multi-attribute rating technique (SMART). Many AHP method applications are suggested in recent researches: Ananda and Herath (2008) synthesised stakeholder preferences related to regional forest planning and to incorporate stakeholder preferences; Cebeci (2009) presented a fuzzy approach to select a suitable enterprise resource planning system for textile industry; Wu et al. (2009) adopted fuzzy AHP to rank the banking performance and improve the gaps with three banks; Colombo et al. (2009) proved that judicious use of AHP by experts can be used to represent citizen views; Štemberger et al. (2009) applied it in business process management; Maskeliūnaite et al. (2009) and Sivilevičius and Maskeliūnaite (2010) solved the problem of improving the quality for passenger transportation; Steuten et al. (2010) used AHP weights to fill missing gaps in Markov decision models; Yan et al. (2011) presented new developments and maintenances of the existing infrastructures under limited government budget and time. Hadi-Vencheh and Niazi-Motlagh (2011) applied improved voting analytic hierarchy process-data envelopment analysis methodology for selection problem. Zavadskas et al. (2012b) applied AHP method for determining managers skill weights.

There are various approaches for assessing weights (Zavadskas et al. 2010a, 2010b), e.g., the eigenvector method, SWARA (Keršuliene et al. 2010), expert method (Zavadskas, Vilutienè 2006), entropy method, etc.

The decision is made by using the derived weights $w$ of the evaluative criteria (Saaty 1980). According to Saaty, his experiments have shown that most individuals cannot compare more than seven objects (plus/minus two). Based on this, Saaty established 9 objects as the upper limit of his integer scale for multiple pairwise comparisons (Table 1). 
Table 1. The nine-point scale of pair wise comparison (according to Saaty 1980)

\begin{tabular}{|c|c|c|c|c|c|c|c|}
\hline $\begin{array}{l}\text { Intensity of } \\
\text { importance }\end{array}$ & 1 & 3 & 5 & 7 & 9 & $2,4,6,8$ & $\begin{array}{c}\text { Reciprocals } \\
\text { nonzero }\end{array}$ \\
\hline 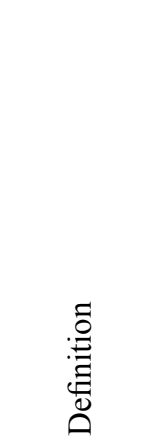 & 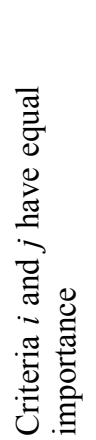 & 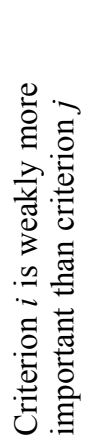 & 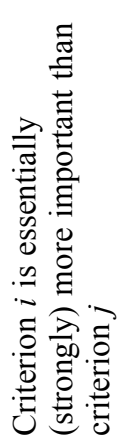 & 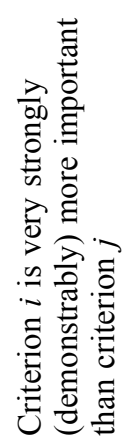 & 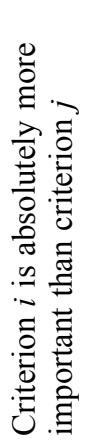 & 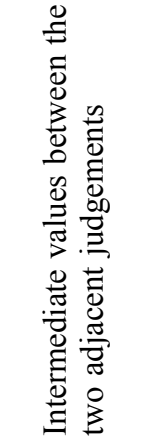 & 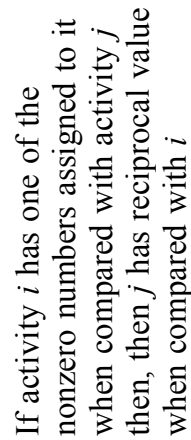 \\
\hline
\end{tabular}

In AHP, the decision matrix is always a square matrix:

$$
\begin{gathered}
A=\left(a_{i j}\right)=\left[\begin{array}{cccc}
1 & \frac{w_{1}}{w_{2}} & \cdots & \frac{w_{1}}{w_{m}} \\
\frac{w_{2}}{w_{1}} & 1 & \cdots & \frac{w_{2}}{w_{m}} \\
\vdots & \vdots & \ddots & \vdots \\
\frac{w_{m}}{w_{1}} & \frac{w_{m}}{w_{2}} & \cdots & 1
\end{array}\right], \\
a_{i i}=1, a_{i j}=\frac{1}{a_{j i}}, a_{i j} \neq 0 .
\end{gathered}
$$

Aggregate weight is determined as follows:

After obtaining the criteria weights from AHP, the synthesising of ratio judgements is done.

Suppose $\tilde{W}=\left[\overline{\tilde{w}_{1}, \tilde{w}_{n}}\right]=\left[\tilde{w}_{j}\right]$ is aggregate weight for $n$ criteria and $\tilde{w}_{j}$ is fuzzy triangular number:

$$
\tilde{w}_{j}=\left(w_{j \alpha}, w_{j \gamma}, w_{j \beta}\right),
$$

where $w_{j \alpha}=\min _{k} y_{j k}, j=\overline{1, n}, k=\overline{1, p}$ is minimum possible value,

$w_{j \gamma}=\left(\prod_{k=1}^{p} y_{j k}\right)^{\frac{1}{p}}, j=\overline{1, n}, k=\overline{1, p}$ is the most possible value and

$w_{j \beta}=\max _{k} y_{j k}, j=\overline{1, n}, k=\overline{1, p}$ is the maximal possible value of $j$-th criterion. 


\section{Application of the developed model}

For the assessment of a chief accounting officer, the set of essential criteria consists of: education, academic level, long life learning, working knowledge, working skills, work experience, culture, competence, team player, leadership excellence, ability to work in different business units, determination of a goal, problem solving ability, decision making skills, strategic thinking, ability to sell self and ideas, interpersonal skills, management experience, emotional steadiness, communication skills, ability to maintain a good discussion, personality assessment, computer skills, self-confidence, fluency in foreign languages, responsibility, patience, effective time using and age.

Bots et al. (2009) wrote "In 2002, the Accountants-in-Business section of the International Federation of Accountants issued the Competency Profiles for Management Accounting Practice and Practitioners report”. Birkett (2002) developed a framework for competencies required of management accountants during their careers. The Birkett Report distinguishes five experience levels of management accountants: the novice practitioner level, the assistant practitioner level, the competent practitioner level, the proficient practitioner level and the expert practitioner level. Each level is characterized by its position in the business hierarchy, activities and performance expectations.

Birkett determined a five-level system of competencies. Level one consists of cognitive skills and behavioural skills. In level two, cognitive skills are divided into technical skills, analytical/design skills, and appreciative skills, while behavioural skills are divided into personal skills, interpersonal skills, and organisational skills. At level three, there are 38 essential skills, 80 skills at level four, and 375 skills are at level five.

The problem's set of criteria was determined by three decision makers (owners) of the company as follows:

$x_{1}$ - Education, academic level, long life learning;

$x_{2}$ - Working knowledge, working skills, work experience, knowledge of legislation system;

$x_{3}$ - Responsibility;

$x_{4}$ - Strategic thinking;

$x_{5}$ - Leadership; ability to work in a team;

$x_{6}$ - Motivation to work in a particular position;

$x_{7}$ - Computer skills;

$x_{8}$ - Ability to work with clients, consultants and community.

At the first stage of problem solving, three decision makers determined criteria ranks by applying AHP method. All of experts prepared pairwise comparison matrixes. In Table 2 is shown of the pairwise comparison matrix (Expert 1). 
Table 2. Pairwise comparisons among criteria

\begin{tabular}{cccccccccccc}
\hline \multicolumn{10}{c}{ Expert 1} \\
\hline & $x_{1}$ & $x_{2}$ & $x_{3}$ & $x_{4}$ & $x_{5}$ & $x_{6}$ & $x_{7}$ & $x_{8}$ & Weights & Products & Ratio \\
\hline$x_{1}$ & 1.00 & 2.00 & 3.00 & 4.00 & 5.00 & 6.00 & 7.00 & 8.00 & 0.33 & 2.78 & 8.51 \\
\hline$x_{2}$ & 0.50 & 1.00 & 2.00 & 3.00 & 4.00 & 5.00 & 6.00 & 7.00 & 0.23 & 1.94 & 8.55 \\
\hline$x_{3}$ & 0.33 & 0.50 & 1.00 & 2.00 & 3.00 & 4.00 & 5.00 & 6.00 & 0.16 & 1.33 & 8.47 \\
\hline$x_{4}$ & 0.25 & 0.33 & 0.50 & 1.00 & 2.00 & 3.00 & 4.00 & 5.00 & 0.11 & 0.90 & 8.33 \\
\hline$x_{5}$ & 0.20 & 0.25 & 0.33 & 0.50 & 1.00 & 2.00 & 3.00 & 4.00 & 0.07 & 0.60 & 8.17 \\
\hline$x_{6}$ & 0.17 & 0.20 & 0.25 & 0.33 & 0.50 & 1.00 & 2.00 & 3.00 & 0.05 & 0.40 & 8.07 \\
\hline$x_{7}$ & 0.14 & 0.17 & 0.20 & 0.25 & 0.33 & 0.50 & 1.00 & 2.00 & 0.03 & 0.27 & 8.07 \\
\hline$x_{8}$ & 0.13 & 0.14 & 0.17 & 0.20 & 0.25 & 0.33 & 0.50 & 1.00 & 0.02 & 0.20 & 8.16 \\
\hline & & & & & & & & $\mathrm{CI}=$ & 0.04 & $\mathrm{CI} / \mathrm{RI}=$ & 0.03 \\
\hline
\end{tabular}

According to the calculations by using Eq. (27) aggregate weights were established (Table 3).

Table 3. Aggregate weights

\begin{tabular}{ccccccccc}
\hline & \multicolumn{3}{c}{ Criteria weights } & \multicolumn{4}{c}{ Aggregate weights } \\
\cline { 2 - 9 } & Expert 1 & Expert 2 & Expert 3 & Expert 4 & Expert 5 & $w_{j \alpha}$ & $w_{j \gamma}$ & $w_{j \beta}$ \\
\hline$x_{1}$ & 0.33 & 0.16 & 0.16 & 0.23 & 0.23 & 0.16 & 0.21 & 0.33 \\
\hline$x_{2}$ & 0.23 & 0.33 & 0.11 & 0.33 & 0.16 & 0.11 & 0.21 & 0.33 \\
\hline$x_{3}$ & 0.16 & 0.23 & 0.07 & 0.16 & 0.07 & 0.07 & 0.13 & 0.23 \\
\hline$x_{4}$ & 0.11 & 0.07 & 0.02 & 0.07 & 0.02 & 0.02 & 0.05 & 0.11 \\
\hline$x_{5}$ & 0.07 & 0.11 & 0.33 & 0.11 & 0.33 & 0.07 & 0.17 & 0.33 \\
\hline$x_{6}$ & 0.05 & 0.03 & 0.23 & 0.03 & 0.11 & 0.03 & 0.08 & 0.23 \\
\hline$x_{7}$ & 0.03 & 0.05 & 0.05 & 0.02 & 0.03 & 0.02 & 0.03 & 0.05 \\
\hline$x_{8}$ & 0.02 & 0.02 & 0.03 & 0.05 & 0.05 & 0.02 & 0.03 & 0.05 \\
\hline & & & & & & & &
\end{tabular}

In this study, the linguistic term set with associated semantics is considered (Table 4).

Table 4. Label set

\begin{tabular}{ccccc}
\hline \multirow{2}{*}{ Label set } & \multirow{2}{*}{ Linguistic term } & \multicolumn{3}{c}{ Fuzzy number } \\
\cline { 3 - 5 } & & $\alpha$ & $\gamma$ & $\beta$ \\
\hline$s_{1}$ & Nothing answered, task was not completed & 0 & 0 & 0.2 \\
\hline$s_{2}$ & Bad & 0 & 0.2 & 0.4 \\
\hline$s_{3}$ & Weak & 0.2 & 0.4 & 0.6 \\
\hline$s_{4}$ & Satisfactory & 0.4 & 0.6 & 0.8 \\
\hline$s_{5}$ & Good & 0.6 & 0.8 & 1.0 \\
\hline$s_{6}$ & Excellent & 0.8 & 1.0 & 1.0 \\
\hline
\end{tabular}


The candidates were rated. Data related to the selection of a chief accounting officer are given in Table 5 .

Table 5. Rating of candidates with respect to subjective criteria

\begin{tabular}{|c|c|c|c|c|c|c|}
\hline \multirow{2}{*}{ Criteria } & \multirow{2}{*}{ Candidates } & \multicolumn{5}{|c|}{ Decision makers } \\
\hline & & $\mathrm{D}_{1}$ & $\mathrm{D}_{2}$ & $\mathrm{D}_{3}$ & $\mathrm{D}_{4}$ & $\mathrm{D}_{5}$ \\
\hline \multirow{3}{*}{$x_{1}$} & $A_{1}$ & $s_{6}$ & $s_{4}$ & $s_{4}$ & $s_{5}$ & $s_{4}$ \\
\hline & $A_{2}$ & $s_{5}$ & $s_{6}$ & $s_{4}$ & $s_{6}$ & $s_{4}$ \\
\hline & $A_{3}$ & $s_{4}$ & $s_{6}$ & $s_{4}$ & $s_{5}$ & $s_{5}$ \\
\hline \multirow{3}{*}{$x_{2}$} & $A_{1}$ & $s_{4}$ & $s_{4}$ & $s_{4}$ & $s_{6}$ & $s_{5}$ \\
\hline & $A_{2}$ & $s_{5}$ & $s_{5}$ & $s_{5}$ & $s_{5}$ & $s_{4}$ \\
\hline & $A_{3}$ & $s_{4}$ & $s_{5}$ & $s_{5}$ & $s_{4}$ & $s_{5}$ \\
\hline \multirow{3}{*}{$x_{3}$} & $A_{1}$ & $s_{5}$ & $s_{4}$ & $s_{5}$ & $s_{5}$ & $s_{5}$ \\
\hline & $A_{2}$ & $s_{6}$ & $s_{6}$ & $s_{4}$ & $s_{4}$ & $s_{4}$ \\
\hline & $A_{3}$ & $s_{5}$ & $s_{5}$ & $s_{5}$ & $s_{4}$ & $s_{4}$ \\
\hline \multirow{3}{*}{$x_{4}$} & $A_{1}$ & $s_{5}$ & $s_{6}$ & $s_{4}$ & $s_{6}$ & $s_{4}$ \\
\hline & $A_{2}$ & $s_{5}$ & $s_{5}$ & $s_{5}$ & $s_{6}$ & $s_{4}$ \\
\hline & $A_{3}$ & $s_{4}$ & $s_{4}$ & $s_{5}$ & $s_{5}$ & $s_{5}$ \\
\hline \multirow{3}{*}{$x_{5}$} & $A_{1}$ & $s_{4}$ & $s_{5}$ & $s_{4}$ & $s_{6}$ & $s_{5}$ \\
\hline & $A_{2}$ & $s_{5}$ & $s_{4}$ & $s_{4}$ & $s_{5}$ & $s_{4}$ \\
\hline & $A_{3}$ & $s_{4}$ & $s_{6}$ & $s_{5}$ & $s_{5}$ & $s_{5}$ \\
\hline \multirow{3}{*}{$x_{6}$} & $A_{1}$ & $s_{5}$ & $s_{6}$ & $s_{5}$ & $s_{4}$ & $s_{4}$ \\
\hline & $A_{2}$ & $s_{6}$ & $s_{5}$ & $s_{4}$ & $s_{6}$ & $s_{5}$ \\
\hline & $A_{3}$ & $s_{5}$ & $s_{6}$ & $s_{5}$ & $s_{5}$ & $s_{5}$ \\
\hline \multirow{3}{*}{$x_{7}$} & $A_{1}$ & $s_{5}$ & $s_{6}$ & $s_{5}$ & $s_{6}$ & $s_{4}$ \\
\hline & $A_{2}$ & $s_{4}$ & $s_{5}$ & $s_{4}$ & $s_{6}$ & $s_{4}$ \\
\hline & $A_{3}$ & $s_{4}$ & $s_{4}$ & $s_{4}$ & $s_{4}$ & $s_{4}$ \\
\hline \multirow{3}{*}{$x_{8}$} & $A_{1}$ & $s_{5}$ & $s_{5}$ & $s_{4}$ & $s_{5}$ & $s_{5}$ \\
\hline & $A_{2}$ & $s_{4}$ & $s_{4}$ & $s_{5}$ & $s_{4}$ & $s_{4}$ \\
\hline & $A_{3}$ & $s_{5}$ & $s_{4}$ & $s_{4}$ & $s_{4}$ & $s_{4}$ \\
\hline
\end{tabular}

According to Tables 4 and 5 the matrix with aggregate weights (Table 6) and fuzzy decision making matrix with aggregate weights were prepared (Table 7).

Suppose $\tilde{W}=\left[\tilde{w}_{1}, \tilde{w}_{n}\right]=\left[\tilde{w}_{j}\right]$ is aggregate weight for $n$ criteria and $\tilde{w}_{j}$ is fuzzy triangular number:

$$
\tilde{w}_{j}=\left(w_{j \alpha}, w_{j \gamma}, w_{j \beta}\right),
$$


where $w_{j \alpha}=\min _{k} y_{j k}, j=\overline{1, n}, k=\overline{1, p}$ is minimum possible value, $w_{j \gamma}=\frac{1}{p} \sum_{i=1}^{p} y_{j k}, j=\overline{1, n}, k=\overline{1, p}$ is the most possible value and $w_{j \beta}=\max _{k} y_{j k}, j=\overline{1, n}, k=\overline{1, p}$ is the maximal possible value of $j$-th criterion.

Table 6. The aggregate weight criteria values

\begin{tabular}{|c|c|c|c|c|c|c|c|c|c|c|c|c|c|c|c|c|}
\hline \multirow{3}{*}{$\begin{array}{l}\text { Crite- } \\
\text { ria }\end{array}$} & \multirow{3}{*}{$\begin{array}{c}\text { Candi- } \\
\text { dates }\end{array}$} & \multicolumn{15}{|c|}{ Ratings } \\
\hline & & \multicolumn{3}{|c|}{$\mathrm{D}_{1}$} & \multicolumn{3}{|c|}{$\mathrm{D}_{2}$} & \multicolumn{3}{|c|}{$\mathrm{D}_{3}$} & \multicolumn{3}{|c|}{$\mathrm{D}_{4}$} & \multicolumn{3}{|c|}{ Group fuzzy } \\
\hline & & $\alpha$ & $\gamma$ & $\beta$ & $\alpha$ & $\gamma$ & $\beta$ & $\alpha$ & $\gamma$ & $\beta$ & $\alpha$ & $\gamma$ & $\beta$ & $\alpha$ & $\gamma$ & $\beta$ \\
\hline \multirow{3}{*}{$x_{1}$} & $A_{1}$ & 0.8 & 1.0 & 1.0 & 0.4 & 0.6 & 0.8 & 0.4 & 0.6 & 0.8 & 0.6 & 0.8 & 1.0 & 0.4 & 0.66 & 1 \\
\hline & $A_{2}$ & 0.6 & 0.8 & 1.0 & 0.8 & 1.0 & 1.0 & 0.4 & 0.6 & 0.8 & 0.8 & 1.0 & 1.0 & 0.4 & 0.73 & 1 \\
\hline & $A_{3}$ & 0.4 & 0.6 & 0.8 & 0.8 & 1.0 & 1.0 & 0.4 & 0.6 & 0.8 & 0.6 & 0.8 & 1.0 & 0.4 & 0.66 & 1 \\
\hline \multirow{3}{*}{$x_{2}$} & $A_{1}$ & 0.4 & 0.6 & 0.8 & 0.4 & 0.6 & 0.8 & 0.4 & 0.6 & 0.8 & 0.8 & 1.0 & 1.0 & 0.4 & 0.62 & 1 \\
\hline & $A_{2}$ & 0.6 & 0.8 & 1.0 & 0.6 & 0.8 & 1.0 & 0.6 & 0.8 & 1.0 & 0.6 & 0.8 & 1.0 & 0.6 & 0.71 & 1 \\
\hline & $A_{3}$ & 0.4 & 0.6 & 0.8 & 0.6 & 0.8 & 1.0 & 0.6 & 0.8 & 1.0 & 0.4 & 0.6 & 0.8 & 0.4 & 0.63 & 1 \\
\hline \multirow{3}{*}{$x_{3}$} & $A_{1}$ & 0.6 & 0.8 & 1.0 & 0.4 & 0.6 & 0.8 & 0.6 & 0.8 & 1.0 & 0.6 & 0.8 & 1.0 & 0.4 & 0.67 & 1 \\
\hline & $A_{2}$ & 0.8 & 1.0 & 1.0 & 0.6 & 0.8 & 1.0 & 0.4 & 0.6 & 0.8 & 0.4 & 0.6 & 0.8 & 0.4 & 0.66 & 1 \\
\hline & $A_{3}$ & 0.6 & 0.8 & 1.0 & 0.6 & 0.8 & 1.0 & 0.6 & 0.8 & 1.0 & 0.4 & 0.6 & 0.8 & 0.4 & 0.67 & 1 \\
\hline \multirow{3}{*}{$x_{4}$} & $A_{1}$ & 0.6 & 0.8 & 1.0 & 0.8 & 1.0 & 1.0 & 0.4 & 0.6 & 0.8 & 0.8 & 1.0 & 1.0 & 0.4 & 0.73 & 1 \\
\hline & $A_{2}$ & 0.6 & 0.8 & 1.0 & 0.6 & 0.8 & 1.0 & 0.6 & 0.8 & 1.0 & 0.8 & 1.0 & 1.0 & 0.6 & 0.73 & 1 \\
\hline & $A_{3}$ & 0.4 & 0.6 & 0.8 & 0.4 & 0.6 & 0.8 & 0.6 & 0.8 & 1.0 & 0.6 & 0.8 & 1.0 & 0.4 & 0.63 & 1 \\
\hline \multirow{3}{*}{$x_{5}$} & $A_{1}$ & 0.4 & 0.6 & 0.8 & 0.6 & 0.8 & 1.0 & 0.4 & 0.6 & 0.8 & 0.8 & 1.0 & 1.0 & 0.4 & 0.66 & 1 \\
\hline & $A_{2}$ & 0.6 & 0.8 & 1.0 & 0.4 & 0.6 & 0.8 & 0.4 & 0.6 & 0.8 & 0.6 & 0.8 & 1.0 & 0.4 & 0.63 & 1 \\
\hline & $A_{3}$ & 0.4 & 0.6 & 0.8 & 0.8 & 1.0 & 1.0 & 0.6 & 0.8 & 1.0 & 0.6 & 0.8 & 1.0 & 0.4 & 0.70 & 1 \\
\hline \multirow{3}{*}{$x_{6}$} & $A_{1}$ & 0.6 & 0.8 & 1.0 & 0.8 & 1.0 & 1.0 & 0.6 & 0.8 & 1.0 & 0.4 & 0.6 & 0.8 & 0.4 & 0.70 & 1 \\
\hline & $A_{2}$ & 0.8 & 1.0 & 1.0 & 0.6 & 0.8 & 1.0 & 0.4 & 0.6 & 0.8 & 0.8 & 1.0 & 1.0 & 0.4 & 0.73 & 1 \\
\hline & $A_{3}$ & 0.6 & 0.8 & 1.0 & 0.8 & 1.0 & 1.0 & 0.6 & 0.8 & 1.0 & 0.6 & 0.8 & 1.0 & 0.6 & 0.73 & 1 \\
\hline \multirow{3}{*}{$x_{7}$} & $A_{1}$ & 0.6 & 0.8 & 1.0 & 0.8 & 1.0 & 1.0 & 0.6 & 0.8 & 1.0 & 0.8 & 1.0 & 1.0 & 0.6 & 0.76 & 1 \\
\hline & $A_{2}$ & 0.4 & 0.6 & 0.8 & 0.6 & 0.8 & 1.0 & 0.4 & 0.6 & 0.8 & 0.8 & 1.0 & 1.0 & 0.4 & 0.66 & 1 \\
\hline & $A_{3}$ & 0.4 & 0.6 & 0.8 & 0.4 & 0.6 & 0.8 & 0.4 & 0.6 & 0.8 & 0.4 & 0.6 & 0.8 & 0.4 & 0.54 & 0.8 \\
\hline \multirow{3}{*}{$x_{8}$} & $A_{1}$ & 0.6 & 0.8 & 1.0 & 0.6 & 0.8 & 1.0 & 0.4 & 0.6 & 0.8 & 0.6 & 0.8 & 1.0 & 0.4 & 0.67 & 1 \\
\hline & $A_{2}$ & 0.4 & 0.6 & 0.8 & 0.4 & 0.6 & 0.8 & 0.6 & 0.8 & 1.0 & 0.4 & 0.6 & 0.8 & 0.4 & 0.59 & 1 \\
\hline & $A_{3}$ & 0.6 & 0.8 & 1.0 & 0.4 & 0.6 & 0.8 & 0.4 & 0.6 & 0.8 & 0.4 & 0.6 & 0.8 & 0.4 & 0.59 & 1 \\
\hline
\end{tabular}


Table 7. The fuzzy decision making matrix with aggregate weights (all criteria should to be maximized and optimal value equals to 1.0)

\begin{tabular}{|c|c|c|c|c|c|c|c|c|c|c|c|c|c|}
\hline \multirow{4}{*}{ Criterion } & \multicolumn{10}{|c|}{ Alternatives } & \multirow{3}{*}{\multicolumn{3}{|c|}{ Total }} \\
\hline & $A_{0}$ & & $A_{1}$ & & & $A_{2}$ & & & $A_{3}$ & & & & \\
\hline & \multicolumn{10}{|c|}{ Ratings } & & & \\
\hline & $\alpha ; \gamma ; \beta$ & $\alpha$ & $\gamma$ & $\beta$ & $\alpha$ & $\gamma$ & $\beta$ & $\alpha$ & $\gamma$ & $\beta$ & $\alpha$ & $\gamma$ & $\beta$ \\
\hline$x_{1}$ & 1.0 & 0.4 & 0.66 & 1 & 0.4 & 0.73 & 1 & 0.4 & 0.66 & 1 & 2.2 & 3.05 & 4 \\
\hline$x_{2}$ & 1.0 & 0.4 & 0.62 & 1 & 0.6 & 0.71 & 1 & 0.4 & 0.63 & 1 & 2.4 & 2.96 & 4 \\
\hline$x_{3}$ & 1.0 & 0.4 & 0.67 & 1 & 0.4 & 0.66 & 1 & 0.4 & 0.67 & 1 & 2.2 & 3 & 4 \\
\hline$x_{4}$ & 1.0 & 0.4 & 0.73 & 1 & 0.6 & 0.73 & 1 & 0.4 & 0.63 & 1 & 2.4 & 3.09 & 4 \\
\hline$x_{5}$ & 1.0 & 0.4 & 0.66 & 1 & 0.4 & 0.63 & 1 & 0.4 & 0.70 & 1 & 2.2 & 2.99 & 4 \\
\hline$x_{6}$ & 1.0 & 0.4 & 0.70 & 1 & 0.4 & 0.73 & 1 & 0.6 & 0.73 & 1 & 2.4 & 3.16 & 4 \\
\hline$x_{7}$ & 1.0 & 0.6 & 0.76 & 1 & 0.4 & 0.66 & 1 & 0.4 & 0.54 & 0.8 & 2.4 & 2.96 & 3.8 \\
\hline$x_{8}$ & 1.0 & 0.4 & 0.67 & 1 & 0.4 & 0.59 & 1 & 0.4 & 0.59 & 1 & 2.2 & 2.85 & 4 \\
\hline
\end{tabular}

Solution results are presented in Table 8 (ARAS-F method) and Table 9 (WPM-F method).

Table 8. The normalized-weighted fuzzy decision making matrix and solution results (ARAS-F method)

Alternatives

\begin{tabular}{|c|c|c|c|c|c|c|c|c|c|c|c|c|}
\hline \multirow[t]{3}{*}{ Criterion } & \multicolumn{3}{|c|}{$A_{0}$} & \multicolumn{3}{|c|}{$A_{1}$} & \multicolumn{3}{|c|}{$A_{2}$} & \multicolumn{3}{|c|}{$A_{3}$} \\
\hline & \multicolumn{12}{|c|}{ Ratings } \\
\hline & $\alpha$ & $\gamma$ & $\beta$ & $\alpha$ & $\gamma$ & $\beta$ & $\alpha$ & $\gamma$ & $\beta$ & $\alpha$ & $\gamma$ & $\beta$ \\
\hline$x_{1}$ & 0.0400 & 0.0689 & 0.1500 & 0.0160 & 0.0454 & 0.1500 & 0.0160 & 0.0503 & 0.1500 & 0.0160 & 0.0454 & 0.1500 \\
\hline$x_{2}$ & 0.0275 & 0.0709 & 0.1375 & 0.0110 & 0.0440 & 0.1375 & 0.0165 & 0.0504 & 0.1375 & 0.0110 & 0.0447 & 0.1375 \\
\hline$x_{3}$ & 0.0175 & 0.0433 & 0.1045 & 0.0070 & 0.0290 & 0.1045 & 0.0070 & 0.0286 & 0.1045 & 0.0070 & 0.0290 & 0.1045 \\
\hline$x_{4}$ & 0.0050 & 0.0162 & 0.0458 & 0.0020 & 0.0118 & 0.0458 & 0.0030 & 0.0118 & 0.0458 & 0.0020 & 0.0102 & 0.0458 \\
\hline$x_{5}$ & 0.0175 & 0.0569 & 0.1500 & 0.0070 & 0.0375 & 0.1500 & 0.0070 & 0.0358 & 0.1500 & 0.0070 & 0.0398 & 0.1500 \\
\hline$x_{6}$ & 0.0075 & 0.0253 & 0.0958 & 0.0030 & 0.0177 & 0.0958 & 0.0030 & 0.0185 & 0.0958 & 0.0045 & 0.0185 & 0.0958 \\
\hline$x_{7}$ & 0.0053 & 0.0101 & 0.0208 & 0.0032 & 0.0077 & 0.0208 & 0.0021 & 0.0067 & 0.0208 & 0.0021 & 0.0055 & 0.0167 \\
\hline$x_{8}$ & 0.0050 & 0.0105 & 0.0227 & 0.0020 & 0.0071 & 0.0227 & 0.0020 & 0.0062 & 0.0227 & 0.0020 & 0.0062 & 0.0227 \\
\hline$\tilde{S}_{i}$ & 0.1253 & 0.3021 & 0.7273 & 0.0512 & 0.2003 & 0.7273 & 0.0566 & 0.2082 & 0.7273 & 0.0516 & 0.1993 & 0.7231 \\
\hline$S_{i}$ & & 0.770 & & & 0.652 & & & 0.661 & & & 0.649 & \\
\hline$K_{i}$ & & 1.000 & & & 0.848 & & & 0.859 & & & 0.844 & \\
\hline
\end{tabular}

According to the ARAS-F method, the second candidate is the best alternative from those available. 


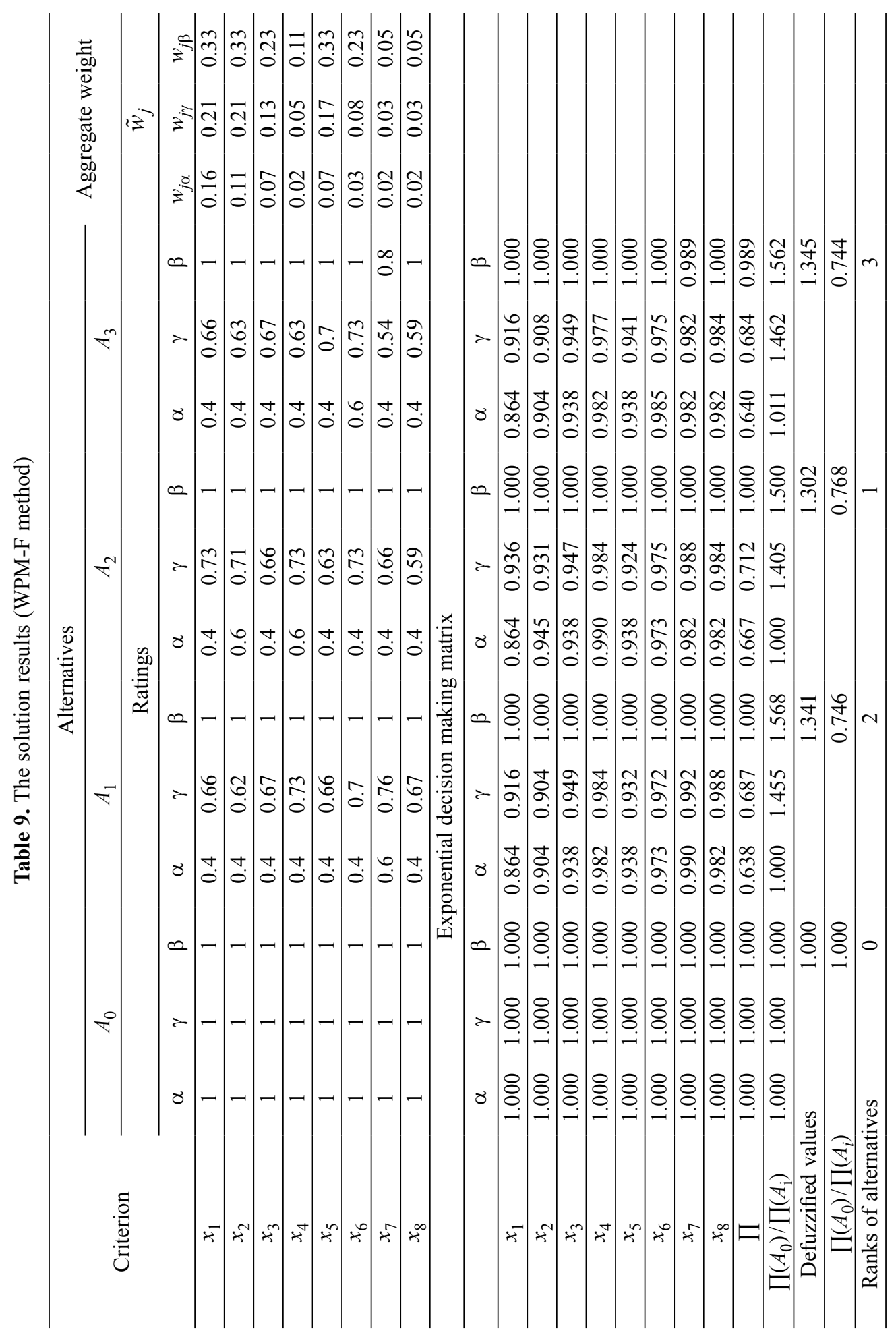


According to the WPM-F and ARAS-F methods alternatives rank as follows $A_{2} \succ A_{1} \succ A_{3}$ (Fig. 4):

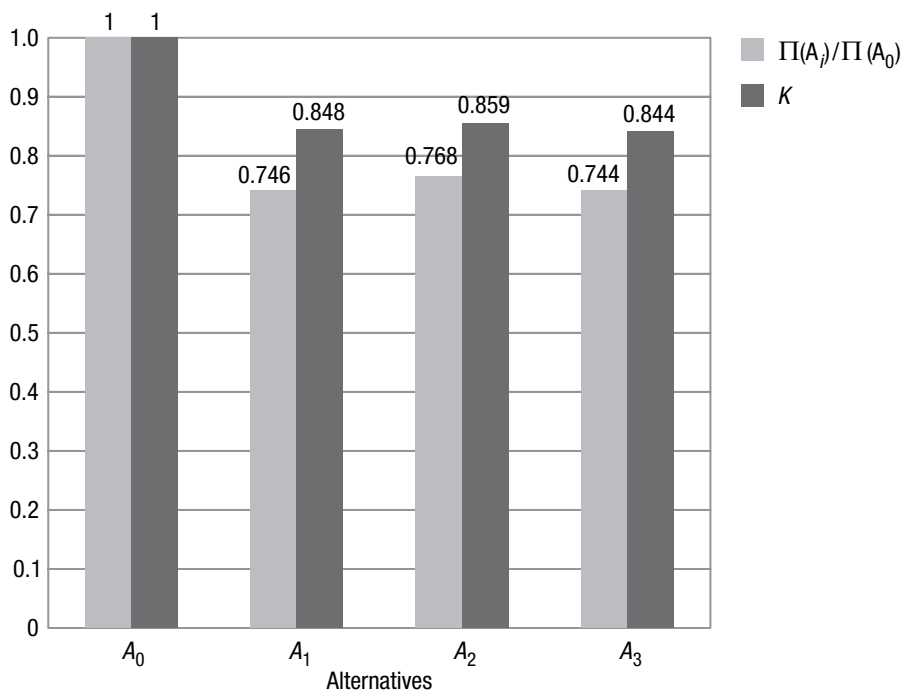

Fig. 4. Ranks of candidates

The best candidate in both solution cases is the second candidate. He/she was selected by decision-makers.

\section{Conclusions}

In the age of competitive markets, appropriate selection of personnel determines success of organisations. A chief accounting officer is one of the most important persons in each organisation. The proposed model helps to overcome difficulties in the selection of a chief accounting officer. The values of criteria set describing candidates in most cases are lexical values. The fuzzy set theory is the proper way to deal with uncertainty. It can be stated that the effectiveness ratio with an optimal alternative may be used in cases when it is sought to rank alternatives and find ways to improve them. The presented case study showed that this model could successfully help in cases when actors need to select from feasible candidates.

\section{References}

Ananda, J.; Herath, G. 2008. Multi-attribute preference modelling and regional land-use planning, Ecological Economics 65(2): 325-335.

http://dx.doi.org/10.1016/j.ecolecon.2007.06.024

Bakshi, T.; Sarkar, B. 2011. MCA based performance evaluation of project selection, International Journal of Software Engineering \& Applications (IJSEA) 2(2): 14-22.

http://dx.doi.org/10.5121/ijsea.2011.2202 
Birkett, W. P. 2002. Competency profiles for Management Accounting Practice and Practitioners. A report of the AIB, Accountants in Business section of the International Federation of Accountants. New York: IFAC. Birkett, 179-189.

Bots, J. M.; Groenland, E.; Swagerman, D. M. 2009. An empirical test of Birkett's competency model for management accountants: survey evidence from Dutch practitioners, Journal of Accounting Education 27(1): 1-13. http://dx.doi.org/10.1016/j.jaccedu.2009.06.001

Cebeci, U. 2009. Fuzzy AHP-based decision support system for selecting ERP systems in textile industry by using balanced scorecard, Expert Systems with Applications 36(5): 8900-8909. http:// dx.doi.org/10.1016/j.eswa.2008.11.046

Chiapello, E.; Medjad, K. 2009. An unprecedented privatisation of mandatory standard-setting: the case of European accounting policy, Critical Perspectives on Accounting 20(4): 448-468. http://dx.doi.org/10.1016/j.cpa.2008.09.002

Chien, C.-F.; Chen, L.-F. 2008. Data mining to improve personnel selection and enhance human capital: a case study in high-technology industry, Expert Systems with Applications 34(1): 280-290. http://dx.doi.org/10.1016/j.eswa.2006.09.003

Colombo, S.; Angus, A.; Morris, J.; Parsons, D. J.; Brawn, M.; Stacey, K.; Hanley, N. 2009. A comparison of citizen and "expert" preferences using an attribute-based approach to choice, Ecological Economics 68(11): 2834-2841. http://dx.doi.org/10.1016/j.ecolecon.2009.06.001

Dursun, M.; Karsak, E. E. 2010. A fuzzy MCDM approach for personnel selection, Expert Systems with Applications 37(6): 4324-4330. http://dx.doi.org/10.1016/j.eswa.2009.11.067

Gammie, E.; Kirkham, L. 2008. Breaking the link with a university education in the creation of a chartered accountant: the ICAS story, The British Accounting Review 40(4): 356-375. http://dx.doi.org/10.1016/j.bar.2008.06.002

Hadi-Vencheh, A.; Niazi-Motlagh, M. 2011. An improved voting analytic hierarchy process-data envelopment analysis methodology for suppliers selection, International Journal of Computer Integrated Manufacturing 24(3): 189-197. http://dx.doi.org/10.1080/0951192X.2011.552528

Heidhues, E.; Patel, C. 2011. A critique of Gray's framework on accounting values using Germany as a case study, Critical Perspectives on Accounting 22(3): 273-287.

http://dx.doi.org/10.1016/j.cpa.2010.08.002

Jones, T. C.; Lee, B. 1998. Accounting, strategy and AMT investment, Omega 26(6): 769-783. http://dx.doi.org/10.1016/S0305-0483(98)00019-X

Kelemenis, A.; Askounis, D. 2010. A new TOPSIS-based multi-criteria approach to personnel selection, Expert Systems with Applications 37(7): 4999-5008.

http://dx.doi.org/10.1016/j.eswa.2009.12.013

Kelemenis, A.; Ergazakis, K.; Askounis, D. 2011. Support managers' selection using an extension of fuzzy TOPSIS, Expert Systems with Applications 38(3): 2774-2782.

http://dx.doi.org/10.1016/j.eswa.2010.08.068

Keršuliene, V.; Turskis, Z. 2011. Integrated fuzzy multiple criteria decision making model for architect selection, Technological and Economic Development of Economy 17(4): 645-666.

http://dx.doi.org/10.3846/20294913.2011.635718

Keršuliene, V.; Zavadskas, E. K.; Turskis, Z. 2010. Selection of rational dispute resolution method by applying new step-wise weight assessment ratio analysis (SWARA), Journal of Business Economics and Management 11(2): 243-258. doi: 10.3846 / jbem. 010.12

Klir, G. J.; Yuan, B. 1995. Fuzzy sets and fuzzy logic: theory and applications. Upper Saddle River, New Jersey: Prentice Hall PTR.

Lambert, C.; Pezet, E. 2011. The making of the management accountant - becoming the producer of truthful knowledge, Accounting, Organizations and Society 36(1): 10-30.

http://dx.doi.org/10.1016/j.aos.2010.07.005 
Lin, H.-T. 2010. Personnel selection using analytic network process and fuzzy data envelopment analysis approaches, Computers \& Industrial Engineering 59(4): 937-944.

http://dx.doi.org/10.1016/j.cie.2010.09.004

Lin, Z. J. 2008. A factor analysis on knowledge and skill components of accounting education: Chinese case, Advances in Accounting 24(1): 110-118.

http://dx.doi.org/10.1016/j.adiac.2008.05.009

Lootsma, F. A. 1993. Scale sensitivity in the multiplicative AHP and SMART, Journal of MultiCriteria Decision Analysis 2(2): 87-110. http://dx.doi.org/10.1002/mcda.4020020205

Maskeliūnaite, L.; Sivilevičius, H.; Podvezko, V. 2009. Research on the quality of passenger transportation by railway, Transport 24(2): 100-112.

http://dx.doi.org/10.3846/1648-4142.2009.24.100-112

Penney, L. M.; Borman, W. C. 2005. The prediction of contextual performance, in A. Evers, A. Anderson, O. Voskuijl (Eds.). Handbook of personnel selection. UK, Oxford: Blackwell, 376-396.

Penney, L. M.; David, E.; Witt, L. A. 2010. A review of personality and performance: identifying boundaries, contingencies, and future research directions, Human Resource Management Review 21(4): 297-310. http://dx.doi.org/10.1016/j.hrmr.2010.10.005

Primrose, P. L. 1988. The motivation for manufacturing investment, in B. Worthington (Ed.). Advances in Manufacturing Technology III: Proceedings of the Fourth National Conference on Production Research, September, 1988, Sheffield City Polytechnic. London: Kogan Page.

Saaty, T. L. 1977. A scaling method for priorities in hierarchical structures, Journal of Mathematical Psychology 15: 234-281. http://dx.doi.org/10.1016/0022-2496(77)90033-5

Saaty, T. L. 1980. The analytical hierarchy process. New York: McGraw-Hill.

Saaty, T. L.; Zoffer, H. J. 2011. Negotiating the Israeli-Palestinian controversy from a new perspective, International Journal of Information Technology \& Decision Making 10(01): 5-64. http://dx.doi.org/10.1142/S021962201100421X

Seifert, D. L.; Sweeney, J. T.; Joireman, J.; Thornton, J. M. 2010. The influence of organizational justice on accountant whistle blowing, Accounting, Organizations and Society 35(7): 707-717. http://dx.doi.org/10.1016/j.aos.2010.09.002

Sivilevičius, H.; Maskeliūnaite, L. 2010. The criteria for identifying the quality of passengers' transportation by railway and their ranking using AHP method, Transport 25(4): 368-381.

http://dx.doi.org/10.3846/transport.2010.46

Sušinskas, S.; Zavadskas, E. K.; Turskis, Z. 2011. Multiple criteria assessment of pile-columns alternatives, The Baltic Journal of Road and Bridge Engineering 6(3): 77-83.

http://dx.doi.org/10.3846/bjrbe.2011.19

Štemberger, M. I.; Bosilj-Vukšić, V.; Jaklič, J. 2009. Business process management software selection - two case studies, Economic Research 22(4): 84-99.

Tillmann, K.; Goddard, A. 2008. Strategic management accounting and sense-making in a multinational company, Management Accounting Research 19(1): 80-102.

http://dx.doi.org/10.1016/j.mar.2007.11.002

Triantaphyllou, E.; Lin, C.-T. 1995. Development and evaluation of five fuzzy multiattribute decision-making methods, International Journal of Approximate Reasoning 14: 281-310.

http://dx.doi.org/10.1016/0888-613X(95)00119-2

Tupenaite, L.; Zavadskas, E. K.; Kaklauskas, A.; Turskis, Z.; Seniut, M. 2010. Multiple criteria assessment of alternatives for built and human environment renovation, Journal of Civil Engineering and Management 16(2): 257-266. http://dx.doi.org/10.3846/jcem.2010.30

Turskis, Z.; Zavadskas E. K. 2010b. A novel method for multiple criteria analysis: grey additive ratio assessment (ARAS-G) method, Informatica 21(4): 597-610. 
Turskis, Z.; Zavadskas, E. K. 2010a. A new fuzzy additive ratio assessment method (ARAS-F). Case study: the analysis of fuzzy multiple criteria in order to select the logistic centers location, Transport 25(4): 423-432. http://dx.doi.org/10.3846/transport.2010.52

Turskis, Z.; Lazauskas, M.; Zavadskas, E. K. 2012. Fuzzy multiple criteria assessment of construction site alternatives for non-hazardous waste incineration plant in Vilnius city, applying ARAS-F and AHP methods, Journal of Environmental Engineering and Landscape Management 20(2): 110-120. http://dx.doi.org/10.3846/16486897.2011.645827

Van Laarhoven, P. J. M.; Pedrycz, W. 1983. A fuzzy extension of Saaty's priority theory, Fuzzy Sets and Systems 11: 229-241. http://dx.doi.org/10.1016/S0165-0114(83)80082-7

Wu, H.-Y.; Tzeng, G.-H.; Chen, Y.-H. 2009. A fuzzy MCDM approach for evaluating banking performance based on Balanced Scorecard, Expert Systems with Applications 36(6): 1013510147. http://dx.doi.org/10.1016/j.eswa.2009.01.005

Yan, M. R.; Pong, C. S.; Lo, W. 2011. Utility-based multicriteria model for evaluating BOT projects, Technological and Economic Development of Economy 17(2): 207-218.

http://dx.doi.org/10.3846/20294913.2011.580585

Zadeh, L. A. 1975a. Fuzzy logic and its application to approximate reasoning, Part I, Information Science 8(3): 199-249. http://dx.doi.org/10.1016/0020-0255(75)90036-5

Zadeh, L. A. 1975b. Fuzzy logic and its application to approximate reasoning, Part II, Information Science 8(4): 301-357. http://dx.doi.org/10.1016/0020-0255(75)90046-8

Zadeh, L. A. 1975c. Fuzzy logic and its application to approximate reasoning, Part III, Information Science 9(1): 43-80. http://dx.doi.org/10.1016/0020-0255(75)90017-1

Zadeh, L. A. 1975d. The concept of a linguistic variable and its application to approximate reasoning-II, Information Sciences 8: 301-357. http://dx.doi.org/10.1016/0020-0255(75)90046-8

Zavadskas, E. K.; Turskis, Z. 2010. A new additive ratio assessment (ARAS) method in multicriteria decision-making, Technological and Economic Development of Economy 16(2): 159-172. http://dx.doi.org/10.3846/tede.2010.10

Zavadskas, E. K.; Turskis, Z. 2011. Multiple criteria decision making (MCDM) methods in economics: an overview, Technological and Economic Development of Economy 17(2): 397-427. http://dx.doi.org/10.3846/20294913.2011.593291

Zavadskas, E. K.; Turskis, Z.; Ustinovichius, L.; Shevchenko, G. 2010a. Attributes weights determining peculiarities in multiple attribute decision making methods, Inzinerine Ekonomika Engineering Economics (1): 32-43.

Zavadskas, E. K.; Turskis, Z.; Vilutiene, T. 2010b. Multiple criteria analysis of foundation instalment alternatives by applying Additive Ratio Assessment (ARAS) method, Archives of Civil and Mechanical Engineering 10(3): 123-141. http://dx.doi.org/10.1016/S1644-9665(12)60141-1

Zavadskas, E. K.; Vilutienė, T. 2006. A multiple-criteria evaluation of multi-family apartment block maintenance contractors: I-Model for maintenance contractor evaluation and the determination of its selection criteria, Building and Environment 41(5): 621-632.

http://dx.doi.org/10.1016/j.buildenv.2005.02.019

Zavadskas, E. K.; Sušinskas, S.; Daniūnas, A.; Turskis, Z.; Sivilevičius, H. 2012a. Multiple criteria selection of pile-column construction technology, Journal of Civil Engineering and Management 18(6): 858-866. http://dx.doi.org/10.3846/13923730.2012.744537

Zavadskas, E. K.; Vainiunas, P.; Turskis, Z.; Tamosaitiene, J. 2012b. Multiple criteria decision support system for assessment of projects managers in construction, International Journal of Information technology \& Decision making 11(2): 501-520.

http://dx.doi.org/10.1142/S0219622012400135 
Zimmermann, H.-J. 2000. An application-oriented view of modelling uncertainty, European Journal of Operational Research 122(2): 190-198.

http://dx.doi.org/10.1016/S0377-2217(99)00228-3

Zimmermann, H. J. 1985. Fuzzy set theory and its applications. Dordrecht: Kluwer Academic. http://dx.doi.org/10.1007/978-94-015-7153-1

Violeta KERŠULIENĖ. Doctor, Assoc. Prof., Director of Legal Affairs at the Department of Law of Vilnius Gediminas Technical University, Lithuania. Author of 14 scientific papers. In 1991, she graduated from the Civil Engineering Faculty of Vilnius Gediminas Technical University and in 2008, she defended her doctoral thesis in the field of technological sciences. In 1999, she acquired the lawyer's qualification from the Faculty of Law of Vilnius University. Her research interests include decisionmaking, dispute resolution and decision support systems.

Zenonas TURSKIS. Professor, senior research fellow at the Construction Technology and Management Laboratory of Vilnius Gediminas Technical University, Lithuania. His research interests include building technology and management, decision-making theory, computer-aided design and expert systems. Author of more than 90 research papers. 